\title{
EU Migration Law Shaping International Migration Law in the Field of Expulsion of Aliens - the Case of the ILC Draft Articles
}

\author{
TAMÁS MolnÁR*
}

\begin{abstract}
Since the Treaty of Maastricht, EU law has become more open to international law and has engaged with it in different forms of interactions. The influence of EU law on universal law-making has found its way through different legal channels and techniques. The article thoroughly scrutinizes the impact of EU return acquis on the development of the international law governing the 'expulsion of aliens', which can be best analysed through the work of the UN International Law Commission (ILC) on the expulsion of aliens (2004-2014). The ILC's approach has come a long way from the mere ignorance of EU law and the EU's submissions by the special rapporteur in the early stages of the codification work until it has gradually taking into account major EU migration law concepts in ILC reports and in the draft articles. The 2014 ILC draft articles on the expulsion of aliens have finally been, in many aspects, inspired and influenced by EU law, especially the Return Directive (2008/115/EC). This short piece meticulously explores the inroads EU return law made in relation to the ILC work on the expulsion of aliens, by identifying and critically evaluating the tangible impact of EU law on the UN codification project. Keywords: Expulsion of aliens, interactions between EU law and international law, International Law Commission, Return Directive
\end{abstract}

\section{PROLOGUE}

This article deals with the interactions of two functionally differentiated normative layers, i.e. supranational law (European Union (EU) law) and general international law, notably law-making within the United Nations in the expulsion of aliens, a specific field of international migration law. Since the Treaty of Maastricht (1992), EU law became more open to international law and has engaged with it in different forms of interactions. Looking at those interactions from an inside out perspective, an ever-increasing treaty-making activity of the Union ${ }^{1}$ can be seen, e.g. the European External Action Service database on international treaties to which the Union is a party, ${ }^{2}$ and the EU's various attempts to shape the international legal order. This dimension of exporting EU law to international law or influencing the creation of international law more generally, ${ }^{3}$ which external normgenerating approach was graved into primary law by the Lisbon Treaty. Article 3(5) of the Treaty on European Union" (TEU) stipulates that '[i]n its relations with the wider world, the Union shall $[\ldots]$ contribute $[\ldots]$ to the strict observance and the development of

* Legal research officer on migration, asylum and borders, European Union Agency for Fundamental Rights, Vienna; adjunct professor of public international law and EU migration law, Corvinus University of Budapest, Institute of International Studies (currently on leave). E-mail: tamas.molnar@uni-corvinus.hu. The views expressed in this chapter are solely those of the author and its content does not necessarily represent the views or the position of the European Union Agency for Fundamental Rights. This article was supported by the János Bolyai Research Scholarship of the Hungarian Academy of Sciences.

1 See e.g. the figures from Bergé (2009) 12.

2 See $<$ http://ec.europa.eu/world/agreements/viewCollection.do $>$ accessed 30 April 2017.

3 Ziegler (2011) 277, 310.

4 Treaty on European Union (OJ C 115, 9.5.2008). 
international law, including respect for the principles of the United Nations Charter.' This obligation is complemented by Article 21(1) TEU: 'Union's action on the international scene shall be guided by [...] the principles which have inspired its own creation, [including the] respect for the principles of the United Nations Charter and international law.' Further more, in pursuing this general objective, the EU shall 'consolidate and support [...] the principles of international law' as ordered by the Article 21 (2) TEU.

The active role of EU law in international law-making can now be perceived in various domains. The contribution of EU law to influence universal legal norms finds its way through different legal channels and techniques, e.g. within international organisations like the United Nations and its specialised agencies and the Council of Europe, in agenda setting in international fora and during international conferences leading to the adoption of multilateral treaties, coupled with exporting its own approaches to the functioning of international law. ${ }^{5}$ The paper thoroughly scrutinizes the impact of EU law on the conceptualization and the development of a particular field of international migration law. This is the legal regime applicable to the 'expulsion of aliens', the term used by the International Law Commission (ILC), or 'return law/policy' in the EU context. In international law, 'expulsion' means a formal act or conduct attributable to a State by which a non-national is compelled to leave the territory of that State but it does not include extradition to another State; surrender to an international criminal court or the nonadmission to a State. ${ }^{6}$ EU law applies a similar, albeit more limited definition for expulsion which has been baptised to 'return decision'. It denotes 'an administrative or judicial decision or act, stating or declaring the stay of a [non-EU national] to be illegal and imposing or stating an obligation to return', ${ }^{7}$ whereas 'return' is defined as the process of a non-EU national going back, whether in voluntary compliance with a return decision or enforced, to the country of origin, a transit country or any other third country willing to accept the returnee. ${ }^{8}$ All these State prerogatives are rooted in the well-established principle of international law that States have the right to control the entry, residence and expulsion of aliens, subject to their treaty obligations and limitations stemming from customary international law. ${ }^{9}$

The 'Area of Freedom, Security and Justice' within the Union's legal architecture, where return law and policy belong to, has played the role of a 'innovative ideas laboratory' and can thus be conceived as a forerunner in the further development of EU integration and the creation of new EU concepts. Along similar lines, these EU migration law concepts can

5 See e.g. Wouters and Hermez (2016); Kochenov and Amtenbrink (2014); Basu, Schunz, Bruyninckx and Wouters (2012) 3-22.

${ }^{6}$ International Law Commission, Report on the Work of Its Sixty-Sixth Session, Draft Articles on the Expulsion of Aliens, GAOR, $69^{\text {th }}$ session, Supplement No. 10 (A/69/10) (2014), draft article 2 (a).

7 Directive 2008/115/EC of the European Parliament and of the Council of 16 December 2008 on common standards and procedures in Member States for returning illegally staying third-country nationals (OJ L 348, 12.24.2008) (hereinafter: 'Return Directive'), Article 3(4).

${ }^{8}$ Return Directive, Article 3(3).

9 For instance, the jurisprudence of the European Court of Human Rights has repeatedly echoed this as a matter of international law (see e.g. Üner $v$ the Netherlands App no 410/99 (ECtHR, 18 October 2006), para. 54; Boujlifa v France App no 25404/94 (ECtHR, 21 October 1997), para. 42; Abdulaziz, Cabales and Balkandali v the United Kingdom App no 24888/94 (ECtHR, 28 May 1985), para. 67. 
be helpful and useful when codifying and progressively developing a given domain of international migration law.

The paper first examines terminological questions to construct a common vocabulary and mutual understanding of international and EU law concepts (Section 2). It then proceeds by outlining the patterns of interactions between the two legal orders in the field of migration law (Section 3). Section 4 maps the EU law contribution to the ILC's work on the expulsion of aliens and is followed by the analysis of the actual impact of EU law on the ILC codification project called 'expulsion of aliens' (Section 5). The paper ends with some concluding remarks (Section 6).

\section{TERMINOLOGIES}

Under international law, notably in light of the 2014 draft articles on the expulsion of aliens (with commentaries), prepared by the ILC ${ }^{10}$ the term 'aliens' is quite a broad and allencompassing notion, covering all kinds of aliens, i.e. individuals not holding the nationality of the State in where they are present, who stay in a given country, irrespective of their lawful or unlawful stay. ${ }^{11}$

In the context of EU law, if one departs from the legality of stay of non-nationals (or aliens' in the ILC vocabulary), the category of 'lawfully staying aliens', on the one hand, covers a great variety of foreigners. It ranges from the diverse group of EUharmonised statuses for third country nationals, under the directives on family reunification (2003/86/EC), long-term stay (2003/109/EC), students, researchers, trainees and au pairs (EU 2016/801); highly-skilled workers (2009/50/EC); seasonal workers (2014/36/EU); intra-corporate transferees (2014/66/EU); holders of a single permit (2011/98/EU) as well as those travelling with a local border traffic permit (Reg. 1931/2006/EC) or on a Schengen visa (Reg. 810/2009/EC) ${ }^{12}$ through third country nationals covered by an EU partnership, stability or association agreement concluded with a third country, e.g., with Turkey or Tunisia, ${ }^{13}$ to persons enjoying the right of free movement within the European Economic Area (EEA) (citizens of the EEA Member States and Switzerland and their family members, in line with Directive 2004/38/EC ${ }^{14}$ ).

10 Expulsion of aliens - Text of the draft articles and commentaries thereto, Report of the International Law Commission, Sixty-sixth session, GAOR, $69^{\text {th }}$ session, Supplement No 10, A/69/10 (2014).

${ }^{11}$ Cf. draft article 2(1) lit. (b), which stipulates that 'alien' means an individual who does not have the nationality of the State in whose territory that individual is present, and the commentary to draft article 1 (para. 3), which makes explicit that ' $[\mathrm{t}]$ he draft articles cover the expulsion of both aliens lawfully present and those unlawfully present in the territory of the expelling State...' (Expulsion of aliens - Text of the draft articles and commentaries thereto, supra note 8).

12 For an overview of these secondary EU law instruments, see Gyeney and Molnár (2016) $183-249$.

13 See the Agreement creating an association between the European Economic Community and Turkey (OJ L 217, 29.12.1964) and the Euro-Mediterranean Agreement establishing an association between the European Communities and their Member States, of the one part, and the Republic of Tunisia, of the other part (OJ L 97, 30.03.1998).

14 Directive 2004/38/EC of the European Parliament and the Council of 29 April 2004 on the right of citizens of the Union and their family members to move and reside freely within the territory of the Member States amending Regulation (EEC) No 1612/68 and repealing Directives 64/221/EEC, 68/360/EEC, 72/194/EEC, 73/148/EEC, 75/34/EEC, 75/35/EEC, 90/364/EEC, 90/365/EEC and 93/96/EEC (OJ L 158, 30.4.2004) (hereinafter: 'Free Movement Directive'). 
The term 'illegally staying' or 'unlawfully present aliens' also makes up a heterogeneous group under EU law based on the reasons behind their situation. It consists of third-country nationals, i.e. foreigners who do not hold the nationality of any Member State, who entered illegally into the territory of an EU Member State, either through the border crossing points or through 'green' (land) or 'blue' (sea) borders by avoiding the control; overstayers; status changers; rejected asylum seekers and, through the lenses of international law, persons having enjoyed the EU right of free movement if they become an unreasonable burden to the social assistance system of the host Member State or for any other reason they lose the right to freedom of movement. The expulsion of these illegally staying non-nationals (aliens) under EU law is regulated essentially by the Return Directive $(2008 / 115 / \mathrm{EC}),{ }^{15}$ with respect to third-country nationals without the right to stay, ${ }^{16}$ and to a much lesser extent, concerning the last category (EU/EEA citizens and persons assimilated with them), the Free Movement Directive (Directive 2004/38/EC). ${ }^{17}$

The study restricts itself to the '(illegally staying) third-country nationals' and the rules relating to their expulsion under review in light of international law and EU law - namely how the Union has tried to influence the shaping of the legal norms of universal character with regard to this group of non-nationals. The reason behind this limitation is that the concept of 'third-country nationals' (persons who do not possess the nationality of an EU Member State - EU parlance) is essentially equal, from the perspective of EU law, with the term 'aliens' used in the work of the ILC. This makes the comparison between EU law and international law simpler and more accurate. This approach is explained by the fact that persons enjoying the right of free movement within the EU constitute a privileged, specific group for which the general rules of expulsion do not apply - they are subject to enhanced protection and further guarantees against expulsion as stipulated by Directive 2004/38/EC. EU law operates with a clear distinction between the legislation addressed to EU/EEA citizens and family members and the legislation addressed to third-country nationals on which legal distinction is also apparent form the consistent case-law of the CJEU. ${ }^{18}$

\section{SPECIFIC INTERACTIONS BETWEEN EU LAW AND INTERNATIONAL LAW IN FIELD OF MIGRATION}

The migration and asylum acquis of the European Union has always been drawing on or has been considerably inspired by international migration and refugee law, although so far, a largely unexplored issue how EU migration law relates to international law. ${ }^{19}$ Peers put it as ' $[\mathrm{t}]$ he development of immigration and asylum law within [....] the European Union (EU) [...] necessarily takes place within an international framework, since it

15 For a comprehensive and meticulous analysis of the Directive, see Lutz and Mananashvili (2016) 658-763.

16 The Return Directive defines the term 'illegal stay' as follows: 'the presence on the territory of a Member State, of a third-country national who does not fulfil, or no longer fulfils the conditions of entry as set out in Article 5 of the Schengen Borders Code or other conditions for entry, stay or residence in that Member State' [Article 3(2)].

17 See notably Articles 15, 28, 31 and 33 .

18 Se e.g. Case C-230/97, Criminal proceedings against Ibiyinka Awoyemi, Judgment of the Court of 29 October 1998, ECLI:EU:C:1998:521, paras. 26-30; Case C-371/08, Nural Ziebell v Land Baden-Württemberg, Judgment of the Court of 8 December 2011, ECLI:EU:C:2011:809, para. 73.

19 Maes, Vanheule, Wouters and Foblets (2011) 50. 
principally concerns the regulation of foreign nationals moving to and from foreign countries.' ${ }^{20}$ The influence of external legal norms has been either explicit, as in case of the 1951 Geneva Convention on the Status of Refugees and its 1967 New York Protocol (they now appear in the 'Lisbonised' version of the Treaty on the functioning of the European Union (TFEU) $)^{21}$ ), or implicit, via the infiltration of the internationally protected human rights which are of particular significance for foreigners. The concept of the 'general principles of EU law' provided a legal channel for the latter, of which fundamental rights form an integral part. ${ }^{22}$ The CJEU stipulated: 'international treaties for the protection of human rights on which the member states have collaborated or of which they are signatories, can supply guidelines which should be followed within the framework of Community law' regarding the sources of the fundamental rights protected by the EU legal order, including those applicable to third-country nationals (aliens). ${ }^{23}$ The treaties include the European Convention on Human Rights (ECHR) and its protocols, out of which Protocol No. 4 lays down the prohibition of expulsion of nationals and the prohibition of collective expulsion of aliens, while Protocol No. 7 contains various procedural safeguards relating to expulsion of aliens, which have been repeatedly interpreted and detailed in the case-law of the European Court of Human Rights (ECtHR). ${ }^{24}$ Likewise, the 1966 International Covenant on Civil and Political Rights (ICCPR) is also a relevant treaty source of fundamental rights within the Union, to which all EU Member States are parties. Article 13 of the ICCPR that deals with the modalities of expelling lawfully staying aliens, is interpreted by the general comments and the quasi-jurisprudence of its treaty-body, the Human Rights Committee (HRC). ${ }^{25}$ The 1984 Convention Against Torture (CAT) is a similar international treaty source of inspiration, ratified by all EU Member States, which lays down the universally accepted obligation of non-refoulement (Article 3), protecting any person present under a State's jurisdiction from refoulement. This explicit prohibition, coupled with Articles 6-7 of the ICCPR as interpreted by the HRC, has made non-refoulement an integral component of the prohibition of torture and cruel, inhuman or degrading treatment or punishment, having now the rank of general customary international human rights law. ${ }^{26}$ Secondary EU legislation on migration occasionally refers to treaties and provides them priority vis-à-vis

20 Peers (2011) 64.

21 Article 78 TFEU, which indicates the international legal boundaries of EU asylum acquis, goes beyond the two principal instruments of international refugee law, since it makes reference to 'other relevant treaties', too (e.g. the 1984 UN Convention against Torture).

${ }^{22}$ The leading case is Case 11-70, International Handelsgesellschaft $v$ Einfuhr- und Vorratsstelle Getreide, Judgment of the Court of 17 December 1970, ECLI:EU:C:1970:114.

23 First pronounced in Case 4/73, J. Nold, Kohlen- und Baustoffgroßhandlung v Commission of the European Communities, Judgment of the Court of 14 May 1974, ECLI:EU:C:1974:51. In subsequent jurisprudence, see e.g. Case 44/79, Hauer v Land Rheinland Pfalz, Judgment of the Court of 13 December 1979, ECLI:EU:C:1979:290; or Case C-36/02, Omega, Judgment of the Court of 14 October 2004, ECLI:EU:C:2004:614, para. 35.

${ }^{24}$ For an overview, see e.g. Lambert (2007); or on the changing dynamics in the expulsion related adjudication of the Strasbourg Court, Farahat (2015) 303-22.

${ }^{25}$ See e.g. Maroufidou $v$ Sweden, CCPR/C/12/D/58/1979, 9 April 1981; or UN Human Rights Committee, CCPR General Comment No. 15: The Position of Aliens Under the Covenant, 41 UN GAOR, Supp. No. 40, UN Doc. A/41/40. Annex VI, 11 April 1986, para. 10. For more, consider e.g. Joseph and Castan (2013); Nowak (2005).

26 Goodwin-Gill and McAdam (2007) 142. 
EU law, in the 'without prejudice' or 'non-affectation' clauses, which make the application of international law possible if they lay down more favourable provisions or conditions. ${ }^{27}$

The EU immigration and asylum law has been 'communatarised' by the Treaty of Amsterdam as of 1 May 1999, which transferred the related fields of EU action from the third pillar into the first pillar of the Union. A new Title IV was inserted into the Treaty establishing the European Community (TEC) named as 'Visas, asylum, immigration and other policies related to free movement of persons' within the 'Area of Freedom, Security and Justice'. As a result, 'Community' competence was extended to measures in the fields of asylum, immigration and safeguarding the rights of third-country nationals, external border controls and visa policy.

Therefore, this regulatory field, broadly referred to as 'aliens' law', ${ }^{28}$ is a relatively new field in the Union legal edifice, which has been an EU policy domain for less than two decades. By contrast, by that time, international migration law had become, a robust body of law, although legal scholars still consider it as 'substance without architecture'29 or describe it as a 'giant unassembled juridical jigsaw puzzle, [in which] the number of pieces is still uncertain and the grand design is still emerging'. ${ }^{30}$ It is true that there exists no worldwide codification regulating all legal aspects of international migration, neither does the definition of the term 'migrant' exist under general international law. Nonetheless, there is an ever-increasing, complex web of legal norms, with new treaties and soft law instruments emerging constantly as well as expanding migration-related international jurisprudence. The major universal treaties on migration and refugee law had already been adopted much before the EU has appeared on this scene, such as the 1951 Refugee Convention and its 1967 Protocol and the 1990 International Convention on the Protection of the Rights of All Migrant Workers and Their Family Members as well as the core UN human rights conventions relevant for the rights of migrants [the ICCPR, the CAT or the 1989 Convention on the Rights of the Child (CRC)]. These are coupled with various regional instruments, e.g. in Europe, the ECHR and its Protocols Nos 4 and 7, other Council of Europe $(\mathrm{CoE})$ conventions related to migration ${ }^{31}$ and even soft law documents, for instance the Twenty Guidelines of the Committee of Ministers of the Council of Europe on Forced Return. ${ }^{32}$ The EU could not overlook those developments of international law either on the global or on the regional plane. Arguably, it was not even in the interests of the European integration project not to rely on those previously elaborated and more or less settled norms and standards which have been endorsed and followed by the Member States and served as obvious sources of inspiration and starting points for the EU standard setting activities. This is reflected in the above-mentioned attitude of EU law towards international migration and refugee law, reserving a place for its rules and principles in Union primary

27 See e.g. Article 4(1) of the Return Directive; or Article 3(3) of Directive 2003/109/EC.

${ }^{28}$ EU Statement - United Nations 6th Committee: ILC report on Expulsion of Aliens, New York, 29 October 2010 (hereinafter: '2010 EU Statement'), Part I. A).

29 Aleinkoff (2007) 467-80.

30 Lillich (1984) 122.

31 E.g. the European Convention on establishment of 13 December 1955 (CETS No 19), the European Agreement on Regulations governing the Movement of Persons between Member States of the Council of Europe of 13 December 1957 (CETS No 25), or the European Convention on the Legal Status of Migrant Workers of 24 November 1977 (CETS No 93).

32 Twenty Guidelines of the Committee of Ministers of the Council of Europe on Forced Return, adopted at the 925th Meeting of the Ministers' Deputies, Strasbourg, 4 May 2005. 
law and secondary law along the lines of the above discussed explicit or implicit legal techniques. For the initial period of building a common European immigration and asylum policy, relevant international legal rules, especially international refugee and human rights law, played the role of points of reference or minimum thresholds of protection. ${ }^{33}$

However, this line of conduct has changed in course of less than twenty years. The original approach of importing norms from international law has been paired with a new role of exporting EU norms to international law; trying to shape and to influence general international law-making and codification projects relating to diverse branches of international law. The EU by now has become an active co-creator of international law. ${ }^{34}$ This newly found norm-generator role has been endorsed by the above mentioned primary law provisions on the EU's objectives in relation to the development of international law, inserted into the TEU by the Treaty of Lisbon. The same holds true for the EU's interactions towards international migration law, notably to the expulsion of aliens in the last couple of years. The impact of EU return law on the international legal regime governing the expulsion of aliens can be best analysed through the work of the International Law Commission on the expulsion of aliens. Inspired by the metaphor used by Bruno Simma and Dirk Pulkowski, who described the relationship of the so-called self-contained regimes (including the EU) and general international law as 'planets and the universe', ${ }^{35}$ an extra spin added by the Star Wars epic as an illustration. Here the Galaxy symbolizes general international (migration) law and the Empire denotes the EU, with its flagship instrument on expulsion, the Return Directive (Directive 2008/115/EC), the 'Directive of Shame'. ${ }^{36}$ Looking at EU law through these lenses, being a regulatory framework once borrowing much from international migration law but much criticized because of the Return Directive's alleged deficiencies in protecting the rights of irregular migrants, now shaping international law as a major norm-exporter; one may wonder using the Star Wars metaphor: Has the Empire struck back? The Empire's principal ammunition here is the Return Directive, being the only 'regional instrument under international law' on this subject matter (if one takes the position of the classic and orthodox international lawyer), which is binding on $26 \mathrm{EU}$ Member States, plus on the four non-EU Schengen Associated States ${ }^{37}$ as well as it constitutes a legal obligation for the candidate countries (Albania, the Former Yugoslav Republic of Macedonia, Montenegro, Serbia and Turkey) under their respective bilateral stabilisation and association or association agreements to harmonise their domestic laws as far as possible with its provisions. The Legal Service of the European Commission have argued before the ILC, 'more than thirty states in Europe already have or will have in the

33 Similarly, see Hailbronner and Thym (2016) 25-27; Maes, Vanheule, Wouters and Foblets (2011) 50 .

34 Kochenov and Amtenbrink (2014) xiii. More generally, see e.g. Van Vooren, Blockmans and Wouters (2013).

35 Simma and Pulkowski (2006) 483-529.

36 On the very harsh critiques of the Return Directive from Latin American countries see e.g. Acosta Arcarazo (2009).

37 The practical implementation of the Return Directive in the Member States and in the four additional Schengen Associated Countries was subject to a comprehensive evaluation by the European Commission, the final report of which was published in October 2013 (European Commission DG Home Affairs, Evaluation on the application of the Return Directive (2008/115/EC). Final Report, 22 October $2013<$ http://ec.europa.eu/smart-regulation/evaluation/search/download.do?documentId= 10737855> accessed 30 April 2017). 
near future provisions in their national legislation that contain standards that correspond at a minimum to the Union's Return [D]irective, which sets standards of treatment for nonEU nationals'. ${ }^{38}$ EU legislation, therefore, represents significant regional practice for international law-making of a universal character that should be taken into account by the ILC when trying to codify this area of international law called 'expulsion of aliens'. Furthermore, EU Justice and Home Affairs Law, where return law and policy belongs, has played the role of a 'innovative ideas laboratory' of and can thus be conceived as a forerunner in the further development of EU integration and the creation of new EU legal concepts. Along similar lines, the standards and safeguards of the Return Directive might be helpful and useful when codifying and progressively developing a given domain of international migration law.

The following section will examine first generally and then more specifically, what kind of influence the EU has exercised on the work of the Special Rapporteur of the topic as well as that of the ILC in the consideration of the topic of expulsion of aliens.

\section{THE CONTRIBUTION OF EU LAW TO THE ILC'S WORK ON THE EXPULSION OF ALIENS (2005-2014)}

\subsection{The ILC draft articles on the expulsion of aliens - an overview}

The ILC included this topic on its agenda in 2004 and appointed Maurice Kamto from Cameroon as Special Rapporteur. The work has actually started in 2005 when the Special Rapporteur submitted his preliminary report, ${ }^{39}$ which was subsequently followed by further eight reports analysing various aspects of the law in this area and proposing a series of draft articles that partly codify and partly progressively develop international law. ${ }^{40}$ Thirty-two draft articles were adopted on first reading in 2012, together with commentaries, after seven years of discussions in the ILC's plenary sessions and in its drafting committee. ${ }^{41}$ In 2014 , the ILC revisited on 'second reading' its work concerning the expulsion of aliens, to finalize thirty-one draft articles (with commentaries). The ILC has thus completed its work on the topic and decided to recommend to the UN General Assembly (UNGA) the following two options: 1) to take note of the draft articles on the expulsion of aliens in a resolution with annexing the articles to the resolution (in case of the Articles on the Responsibility of States for Internationally Wrongful Acts which were endorsed by the UNGA in 2001) and to encourage their widest possible dissemination; or 2) to consider, at a later stage, the elaboration of a convention on the basis of the draft articles (UN conventions codifying the law of diplomatic and consular relations or the law of the treaties etc. were born following

38 Statement on behalf of the European Union by Mr. Lucio Gussetti, Director, Legal Service, European Commission, at the UN General Assembly 6th Committee (Legal), 66th session on the Report of the International Law Commission on the work of its sixty-third session on Expulsion of Aliens and on Protection of Persons in the Event of Disasters, New York, 27 October 2011, 2 (hereinafter: '2011 EU Statement').

39 Preliminary report on the expulsion of aliens, by Mr Maurice Kamto, Special Rapporteur, A/CN.4/554, 2 June 2005.

40 See the ILC Analytical Guide on this topic at <http://legal.un.org/ilc/guide/9_12.shtml> accessed 30 April 2017. For a summary of the ILC's work in scholarly journals, see e.g. Murphy (2013) 164; Murphy (2014).

${ }^{41}$ Report of the International Law Commission, Sixty-fourth session, GAOR, 67th session, Supp. No. 10, A/67/10 (2012) (hereinafter: '2012 ILC Report'), Chapter IV. 
this path). The UNGA welcomed the Commission's conclusion of work on the expulsion of aliens and the adoption of draft articles on the subject (with the detailed commentaries) and decided to further consider the Commission's recommendation on the matter at its seventysecond session, in $2017 .{ }^{42}$

The content of the draft articles will not be analysed here as this is not the aim of this paper. Nevertheless, it is worth giving an overview of the structure and the principal legal issues covered therein. In essence, the project endeavoured to strike the delicate balance between acknowledging the sovereign right of States to expel aliens from their territory and to identify (pure codification) or to propose (progressive development of the law) rules that States must follow with a view to protecting the human rights of the aliens. ${ }^{43}$ The text is divided into five main parts. Part One on general provisions deals with the scope ratione materiae and personae of the codification project and the modalities in exercising the right of expulsion by States. Then come the cases of prohibited expulsion, including the particular situation of refugees and stateless persons, the prohibition to deprive someone's nationality for the sole purpose of expulsion or the prohibition of collective expulsion (Part Two). It is followed by the protection of the rights of aliens subject to expulsion, assuming that their expulsion is permitted, in Part Three. This section lays down some general provisions on respecting human dignity and human rights of aliens, comprising the principle of nondiscrimination and moves on with various aspects on the protection in the expelling State, e.g. prohibition of torture, conditions of detention, in the State of destination and in the transit State. Part Four sets out the specific procedural rights enjoyed by the aliens subject to expulsion addressing matters such as the right to receive notice of and challenge the expulsion decision, the right to be represented, the right to free assistance of an interpreter and the suspensive effect of the appeal against an expulsion decision. Finally, Part Five describes certain legal consequences of an unlawful expulsion, which may trigger a right of readmission for the alien, the responsibility of the expelling State and a right of the alien's State of nationality to pursue diplomatic protection.

\subsection{General comments of the EU on the topic}

The EU, being a UN observer with enhanced status since $2011,{ }^{44}$ first intervened before the Sixth (Legal) Committee of the UNGA on the subject of the ILC's work on the topic of expulsion of aliens in 2009 and then this practice became regular with written and oral submissions in the following years (2010-2012 and 2014). ${ }^{45}$ The EU as an entity is usually

42 Resolution adopted by the General Assembly on 10 December 2014 [on the report of the Sixth Committee (A/69/498)], 69/119. Expulsion of aliens, A/RES/69/119, paras. 1 and 3.

43 Tomuschat (2013) 662; Murphy (2014) 1.

${ }^{44}$ UNGA Resolution A/65/276 upgraded the observer status of the EU's participation in the UN to allow it to present common positions, make interventions, present proposals and participate in the general debate of the General Assembly. Further to that, as an observer with enhanced status, the Union has no vote but is party to more than $50 \mathrm{UN}$ multilateral conventions as the only non-State participant. <http://www.consilium.europa.eu/en/policies/unga/> accessed 30 April 2017.

45 On behalf of the EU, the Legal Service of the European Commission has prepared and presented the official submissions on the topic; with one exception in 2010, when the EU Delegation to the UN intervened before the UNGA Sixth Committee (on the basis of the position paper written by the Commission). The practice shows that the EU Commission has remained in the driving seat in this respect even after the entry into force of the Lisbon Treaty, in the framework of which the Commission still ensures the Union's external representation as a matter of principle (Article 17(1) TEU). 
referred to in ILC-related documents as a 'community of States', like a regional grouping of UN Member States. In addition to the EU Member States, candidate countries as well as the countries of the Stabilization and Association Process and potential candidate countries (Ukraine, Moldova, Georgia) also align themselves with the EU statements on this matter, the position of the Union, that is represented before the Sixth Committee of the UNGA, reflects the view of almost forty UN Member States - a fairly significant share of the UN membership.

A good preliminary question to ask is besides the EU general external policy considerations to contribute to the 'strict observance and the development of international law', why the topic of the expulsion of aliens is so important for the EU substance-wise, what kind of tangible benefits flow from the elaboration and universal acceptance of norms reflecting its own standards? One possible answer is that the EU would expect that EU citizens and their family members (falling under the scope ratione personae of the Free Movement Directive), who would be subject to expulsion in a third country, be treated in accordance with these legal standards. In a broader context, the promotion of these standards might be in the interest of all States, and in a similar manner, of the EU, bearing in mind that nationals of any country, and consequently, EU citizens, may find themselves in a situation of illegal stay and/or for other reasons they may qualify as undesirable persons in another country, e.g., because of public security, public policy or national security considerations. ${ }^{46}$ Tomuschat writes that 'with regard to expulsion, every State can find itself on one or the other side, either as the expelling country or the country of destination' ${ }^{47}$ Furthermore, this codification project has served as a great opportunity for the EU to demonstrate to the outside world that the once heavily criticized Return Directive (the 'Directive of Shame'), even by the $\mathrm{UN},{ }^{48}$ is indeed more progressive and human rights driven, setting thus higher protection standards than any other international legal instrument.

The EU, as noted above, started contributing to this topic in autumn 2009, after the fifth report of the Special Rapporteur. ${ }^{49}$ EU law and jurisprudence have already been reflected proprio motu since the initial phase of the codification project in various ILC documents, such as the 2006 Memorandum prepared by the ILC Secretariat, ${ }^{50}$ in the fifth and subsequent reports (and its addenda) of the Special Rapporteur and in the annual ILC Reports. Developments under EU return law have not therefore remained unnoticed before the ILC, even without EU's intervention. The Special Rapporteur has taken the position that the level of substantial and procedural protection which 'aliens' receive under EU law could serve as an example for the international legal set of legal rules proposed by the

${ }^{46}$ Cf. the Statement on behalf of the European Union by Lucio Gussetti, Director, European Commission Legal Service, at the United Nations 67th General Assembly Sixth Committee on the Report of the International Law Commission on the work of its sixty-fourth session on 'Expulsion of Aliens', New York, 1 November 2012, para. 8 (hereinafter: '2012 EU Statement').

47 Tomuschat (2013) 659.

48 See e.g. the critics voiced by the UN Special Rapporteur on the Human Rights of Migrants, Mr François Crépeau [Regional Study: management of the external borders of the European Union and its impact on the human rights of migrants, A/HRC/23/46, 24 April 2013 (Human Rights Council, Twenty-third session, Agenda item 3), para. 47].

49 Fifth report on the expulsion of aliens, by Mr Maurice Kamto, Special Rapporteur, A/CN.4/611, 27 March 2009.

50 Expulsion of aliens, Memorandum by the Secretariat, International Law Commission, Fiftyeighth session, Geneva, 1 May-9 June and 3 July-11 August 2006, A/CN.4/565, 10 July 2006. 
ILC $^{51}$ and on a more general note, he added that regional law is part of international law and cannot be set aside. ${ }^{52}$ Sometimes EU law has been used by the Special Rapporteur as a stepping stone for the progressive development of international law, e.g., regarding to the right to legal aid.

Below are some conclusions from the general observations made by the Union presented by the Legal Service of the European Commission or the EU Delegation to the UN in New York.

a) The EU welcomed the attention paid by various ILC documents to EU law and CJEU case-law but a recurring and horizontal remark of the Union was that in the ILC's work insufficient attention has been paid to the fundamental distinction under EU law between EU citizens and their family members and the legal standards applicable to them, granting them a privileged status, on the one hand; and the non-EU nationals or third country nationals whose legal status falls under a different legal regime on the other hand. ${ }^{53}$ These two separate sets of laws are concurrent and mutually exclusive. ${ }^{54}$ For the purposes of the ILC's work, the EU rules on the expulsion of third-country nationals are of particular importance and not those on the expulsion of the persons enjoying the EU right of free movement by virtue of Directive 2004/38/EC, given that the former group of foreigners is in a comparable situation with 'aliens' generally speaking in international law.

b) The EU also emphasized, contrary what has been suggested by the Special Rapporteur, that there exists no absolute prohibition of discrimination on the basis of nationality in international law. In this regard, the ECtHR has explicitly recognised that the EU Member States are entitled to grant preferential treatment to nationals of other EU Member States, including in matters of expulsion. Furthermore, the ECtHR has also recognized that EU Member States do not breach international law when they expel nonEU nationals in circumstances where they would not be allowed to expel EU citizens (and their family members). According to the Strasburg Court, such preferential treatment does not entail a breach of the non-discrimination provision of Article 14 ECHR as there is an objective and reasonable justification for such preferential treatment, namely that EU Member States belong to a special legal order, which has, in addition, established its own citizenship. ${ }^{55}$ Consequently, the different EU acquis and protection standards applicable to EU citizens and their family members and third-country nationals (non-EU nationals or 'aliens') are in accordance with international law.

c) Another observation was formulated about the non-applicability of the specific standards governing the expulsion of EU citizens (and their family members) to general international lawmaking. The Special Rapporteur was supportive in this respect when he argued that despite the examples taken from EU law and the case-law of the CJEU belong

512010 EU Statement, 1.

52 Ninth report on the expulsion of aliens, submitted by Mr Maurice Kamto, Special Rapporteur, A/CN.4/670, 25 March 2014, para. 19.

53 Déclaration de la Commission Européenne - l'Assemblée Générale des Nations Unies: Rapport de la Commission du droit international - l'expulsion des étrangers, New York, le 27 octobre 2009 (hereinafter: '2009 EU Statement'); and repeated in the 2010 EU Statement and the $2011 \mathrm{EU}$ Statement.

54 Morano-Foadi and Andreadakis (2011) 1075.

55 Moustaquim v Belgium App no 12313/86 (ECtHR, 18 February 1991), para. 49; C v. Belgium App no 21794/93 (ECtHR, 7 August 1996), para. 38, Ponomaryovi v Bulgaria App no 5335/05 (ECtHR, 21 June 2011), para. 54. For more, see e.g. Brouwer and de Vries (2015) 127-30. 
to the 'special legal order of the European Community', the relevant standards (notably the ones relating to expulsion on public order grounds) 'could be safely applied to the expulsion of aliens within the more general framework of international law'. ${ }^{56}$ The EU cautioned that this assumption did not appear safe. ${ }^{57}$ Even an automatic transposition of legal standards developed for EU citizens to third-country nationals finds no legal basis in EU law and jurisprudence but this does not exclude that certain categories of third-country nationals have the right to be treated on a par with nationals of EU Member States on particular subjects, particularly when they enjoy equal treatment in labour market access, education and vocational training or the access to social security. If this mutatis mutandis transplantation lacks within the 'special legal order' of the EU, it would be even harder to argue that the reinforced safeguards against expulsion are capable of being transposed to the level of universal international law. Such a transposition would qualify for the extremely progressive development of international law but by no means would constitute the codification of existing customary international norms on the matter. The EU's opposition to elevate the higher standards elaborated for the expulsion of EU citizens (and their family members) onto the scale of general international law can be explained by the Union's disinterest in reducing the added value of the freedom of movement within the EU borders and consequently, in losing a slice of the privileged status attached to EU citizenship. Horribile dictu - it could be argued that this position reflects a sort of an unspoken attitude of European superiority.

d) The EU observed that treating third-country nationals differently on the basis of their nationality, in matters of expulsion, may be allowed under international law if it is based on well-founded reasons of public policy. This differentiation is reflected in the international treaty-making practice of the Union. ${ }^{58}$ The EU and its Member States have concluded a series of association, partnership and stabilization agreements with third States that grant persons benefiting from these agreements reinforced protection against expulsion, which is often an indirect result of treaty clauses granting economically active persons reciprocal equal treatment with nationals of EU Member States, typically in relation to access to labour market and working conditions. ${ }^{59} \mathrm{~A}$ result of this includes the case-law of the CJEU on the EEC-Turkey Association Agreement which has emphasized the length of residence of Turkish migrant workers in the host Member State as a decisive element to be taken into consideration in expulsion cases. ${ }^{60}$ These agreements give the nationals of the third States concerned an elevated legal status that falls 'somewhere in between' the legal status enjoyed by EU citizens (and their family members) and that of other legally staying

56 Sixth report on the expulsion of aliens by Mr. Maurice Kamto, Special Rapporteur, A/CN.4/625, 19 March 2010, para. 116.

572010 EU Statement, 2.

582010 EU Statement, 3.

592010 EU Statement. It was also recognized in the CJEU case-law; see e.g. Case C-340/97, Nazli v Stadt Nürnberg, Judgment of the Court of 10 February 2000, ECLI:EU:C:2000:77; Case C-337/07, Ibrahim Altun v Stadt Böblingen, Judgment of the Court of 18 December 2008, ECLI:EU:C:2008:744 or Case C-371/08, Nural Ziebell v Land Baden-Württemberg, Judgment of the Court of 8 December 2011, ECLI:EU:C:2011:809 (relating to the 1963 Association Agreement with Turkey); or case C-97/05, Mohamed Gattoussi v Stadt Rüsselsheim, Judgment of the Court of 14 December 2006, ECLI:EU:C:2006:780 (concerning the Euro-Mediterranean Association Agreement with Tunisia).

60 Morano-Foadi and Andreadakis (2011) 1079. 
third-country nationals in general, subject to the EU immigration acquis. In contrast with the preferential treatment under these agreements, nationals of other third countries who have not concluded similar agreements with the EU are not able to rely on such extra safeguards against expulsion.

Against this background, the European Commission flagged in its statement before the UNGA Sixth Committee that some of the CJEU case law on the expulsion of third-country nationals, which has been discussed by the Special Rapporteur, fall under the lex specialis regime of an international agreement concluded between the EU and the third country concerned, e.g. cases regarding Turkish nationals under the EEC-Turkey Association Agreement. ${ }^{61}$ Therefore this specific case case-law is quite misleading, since it does not reflect the main patterns and principles of general EU law on the expulsion of third-country nationals.

e) Finally, the form of the final outcome of the codification work was of utmost importance to the European Union. The EU, agreeing with those members of the ILC and some UN Member States who have repeatedly expressed doubts as to whether this topic should lead into the elaboration of a convention, ${ }^{62}$ has not supported the adoption of draft articles that might serve the basis of a future international convention on the expulsion of aliens but was continually favourable of elaborating guidelines or 'framework principles' ${ }^{63}$ The EU has reiterated that progressive development in this area of international law would not be beneficial ${ }^{64}$ and confirmed its views in October 2014 that the incorporation of the draft articles into a convention on expulsion of aliens 'is not appropriate at this stage'. ${ }^{65}$

\subsection{The EU detailed comments on the reports of the Special Rapporteur and the ILC draft articles: criticism and suggestions}

The EU has made detailed remarks on areas where it felt that the Special Rapporteur had insufficiently addressed or partly misunderstood EU law on the topic of expulsion of aliens before UN organs. The detailed comments start with a seemingly technical problem with the understanding of EU law's specificity and regulatory logic made difficult by the Special Rapporteur. Mr Kamto had 'a tendency to focus at times excessively on fairly dated EU documents, including on legislation that has been repealed and/or replaced'66, e.g. the predecessor legal acts of the Free Movement Directive or only the proposal leading to the

${ }^{61}$ For example, amongst many others (see also footnote 51), Case C-467/02, Inan Cetinkaya $v$ Land Baden-Württemberg, Judgment of the Court of 11 November 2004, ECLI:EU:C:2004:708.

${ }^{62}$ See e.g. the Topical summary of the discussion held in the Sixth Committee of the General Assembly during its sixty-sixth session, prepared by the Secretariat (A/CN.4/650), 20 January 2012, para. 27; then the Eighth report on the expulsion of aliens, by Mr Maurice Kamto, Special Rapporteur, A/CN/4/651, 22 March 2012, paras. 55-57; and the Ninth report of the Special Rapporteur, para. 71.

${ }^{63}$ This 'softer' form was chosen by the ILC e.g. in case of unilateral declarations of States [Guiding Principles Applicable to Unilateral Declarations of States Capable of Creating Legal Obligations (Report of the International Law Commission on the Work of its Fifty-eighth Session, 61 GAOR, Supp. No. 10 (A/61/10), 2006)].

642012 EU Statement, para. 37 (without further specifying the reasons behind this view).

${ }^{65}$ Statement on behalf of the European Union by Lucio Gussetti, Director, European Commission Legal Service, at the 69th United Nations General Assembly Sixth Committee on Agenda item 78 on Expulsion of Aliens, New York, 27 October 2014 (EUUN14-180EN) (hereinafter: '2014 EU Statement').

662010 EU Statement, 3; then echoed in 2011 EU Statement, 1. 
adoption of the Return Directive were mentioned. ${ }^{67}$ References in the works of the ILC to EU law and policy documents that are no longer current obviously go against the authenticity and accuracy of this international codification project.

A related problem was that the significance of the EU Return Directive, the only legally binding and enforceable regional instrument in this field, was not reflected in the reports of the Special Rapporteur during the earlier stages of its work. This only changed with his eighth report in 2012 and by now, further factors underpin the cardinal importance of this Directive, also for the universal international law-making. More than thirty European States have provisions in their national legislation that contain standards corresponding at a minimum to the provisions of the Directive. ${ }^{68}$ A considerable CJEU jurisprudence has been developed in the last couple of years, interpreting and elaborating more on various provisions of the Return Directive ${ }^{69}$ and as a result, this judge-made body of law is comparable to the expulsion related case-law of the ECtHR. In addition, a Return Handbook was recently published by the European Commission, as a 'commentary' to the Directive, with a view to providing 'guidance relating to the performance of duties of national authorities competent for carrying out return related tasks, including police, border guards, migration authorities, staff of detention facilities and monitoring bodies' ${ }^{70}$

Before the adoption of the first version of the draft articles by the ILC in 2012, the EU welcomed these draft articles that were referred to the ILC drafting committee and found that they expressed general principles correspond to the general principles set out in the Return Directive. ${ }^{71}$ Nevertheless, according to the Union's legal assessment, some of the referred draft articles included detailed provisions that went too far and did not reflect general customary international law. For instance, in view of the Union, detention of children in the same conditions as an adult cannot be considered as necessarily constituting cruel, inhuman or degrading treatment under international law. The EU alleged that in certain cases it may be beneficial for children in detention to be accommodated together with their parents. Likewise, the then proposed list of detailed procedural rights ${ }^{72}$ set the bar too high, therefore some of these procedural guarantees do not reflect universal State

${ }^{67}$ See e.g. paras.103-114 and 274 of the Sixth Report prepared by the Special Rapporteur, or para. 2 of the Second Addendum thereto (A/CN.4/625/Add.2). It is striking that the commentaries to the 2014 draft articles still mention the 2005 Commission proposal on the Return Directive (!), and not the Return Directive itself (footnote 131).

682012 EU Statement, para. 5.

69 See e.g. the following cases: C-357/09 PPU, Kadzoev, Judgment of 30 November 2009, ECLI:EU:C:2009:741 (detention - reasons for prolongation; link to asylum related detention); C-61/11 PPU, El Dridi, Judgment of 28 April 2011, ECLI:EU:C:2011:268 (penalisation of illegal stay by imprisonment); C-329/11, Achughbabian, Judgment of 6 December 2011, ECLI:EU:C:2011:807 (penalisation of illegal stay by imprisonment); C-534/11, Arslan, Judgment of 30 May 2013, ECLI:EU:C:2013:343 (return versus asylum related detention); Mahdi, Judgment of 5 June 2014, ECLI:EU:C:2014:1320 (detention - reasons for prolongation and judicial supervision); C-38/14, or C-554/13, Zh. and O., Judgment of 11 June 2015, ECLI:EU:C:2015:377 (criteria for determining voluntary departure period).

70 Commission Recommendation of 27.09.2017 establishing a common 'Return Handbook' to be used by Member States' competent authorities when carrying out return related tasks C(2017) 6505 final, Brussels, 27.09.2017, Annex, 5.

712010 EU Statement, Part II.

72 Revised draft article C1(1). 
practice and/or opinio juris on the subject, ${ }^{73}$ as a result of which they can hardly find support in the large majority of the States.

In 2012, the EU prepared the bulk of its detailed comments and suggestions concentrating essentially on the draft articles that were adopted at first reading in the same year. ${ }^{74}$ In the following, those comments are reviewed article by article which tried to influence the final outcome of the ILC's work. ${ }^{75}$

a) The EU suggested to make the specific rules pertaining to the expulsion of refugees and stateless persons more precise, notably that the rules to which reference was made should be those which are more favourable to the person subject to expulsion.

b) The EU recalled the need to insert the prohibition of discrimination on the grounds of sexual orientation within the scope of the obligation of non-discrimination, in line with Article 19 TFEU and Article 21 of the EU Charter of Fundamental Rights. ${ }^{76}$

c) Health considerations were lacking from the text in relation to the rights of vulnerable persons, which are nonetheless acknowledged by the Return Directive, so the EU suggested the addition of the state of the health of the aliens as a consideration to be taken into account into the text.

d) The EU's contribution concerning the legality of immigration detention and the detention conditions was of central importance. First, the Union suggested separating the questions of detention and its legality from those of the detention conditions (as in the Return Directive). Detention conditions constitute a separate issue, not to be mixed up with the legal basis and permissible grounds for ordering it, which separate treatment was followed by the 2005 CoE Twenty Guidelines on Forced Return ${ }^{77}$ and the Return Directive (Articles 16-17). The EU was of the view that some further limitations should have been added regarding the legal grounds for ordering detention, with a view to preventing arbitrary detention. Similar ones as foreseen in the CoE Twenty Guidelines on Forced Return (Guideline no 6) and in the Return Directive where authorities are allowed to recourse to detention only if other sufficient but less coercive measures cannot be applied effectively in a specific case and only in order to prepare the return and/or carry out the removal process, as stipulated in Article 15(1). Moreover, according to the EU, anyone in immigration detention should be entitled to a speedy judicial review on the lawfulness of the detention. This is an EU law requirement [under Article 15(2) of the Return Directive] and equally stems from international human rights law, especially the 1966 ICCPR [Article 9(4)] and the 1950 ECHR [Article 5(4)]. Reformulated draft articles, splitting the original draft provision into two, have been prepared by the EU, aimed at strengthening the safeguards on detention conditions, e.g., inserting requirements on detention facilities and the separation of detainees from ordinary prisoners and men from women; ensuring access to legal advice and medical care as well as their right to communicate; reflecting the rights of children in detention.

e) The EU proposed modifications to the implementation of the expulsion order to promote more clearly voluntary departure of the returnee, considering it a humane and dignified means to carry out an expulsion decision, in line with the overall logic of the Return Directive. It brings mutual advantages both for the returnee and the expelling State

732010 EU Statement, Part II.

74 See the 2010 ILC Report, Chapter IV, para. 45.

75 The below is largely based on the 2012 EU Statement before the UNGA Sixth Committee.

${ }^{76}$ Charter of Fundamental Rights of the European Union (OJ C 361, 26.10.2012, 391-407).

77 Guidelines no 10-11. 
and implies fewer risks with regard to respect for human rights. ${ }^{78}$ The EU came forward with a modified draft article, inspired by Guideline no 1 of the CoE Twenty Guidelines on Forced Return, about the recognize voluntary departure as preferred over forced return and set forth specific circumstances on the basis of which a reasonable period for voluntary return should be calculated including the length of stay, children attending school, other family and social ties.

f) Stronger emphasis was proposed by the EU to be made on the obligations of the receiving State, namely that the duty of the State of destination to readmit its own nationals or aliens (third-country nationals) whom it has such an international obligation, e.g., based on a bilateral readmission agreement, should be explicitly set out in the draft articles.

g) The EU suggested a more precise drafting concerning the obligation not to expel an alien to a State where their life or freedom would be threatened. This was done in order to avoid the impression that expulsions to countries exercising the death penalty are generally banned. The Union invoked that the constant jurisprudence of the ECtHR on Article 3 of the Convention requires an individualised assessment of the risk of death penalty in each case. Therefore, the EU prepared a rearranged draft article making reference to this further precondition, i.e. no return is possible to such a State unless an assurance was previously given that death penalty will not be imposed or if imposed, will not be carried out.

h) The EU articulated several comments regarding the procedural rights of aliens subject to expulsion since the issue of procedural safeguards was considered as having outmost importance and is already fairly developed under EU return law. It was suggested that the ILC should elaborate more on the 'right to receive a legal notice' on expulsion and thus to explicitly refer to the right to receive written notice of the expulsion decision and information about the available legal remedies, standards clearly recognised by the $\mathrm{CoE}$ Twenty Guidelines on Forced Return and the Return Directive. ${ }^{79}$ Secondly, the Union underlined that the right to be heard by a competent authority does not necessarily imply the right to be heard in person. The alien should be provided with an opportunity to explain their situation and submit their own reasons before the competent authority. In some circumstances, this means that written proceedings may satisfy the requirements of international law. Thirdly, the EU did not agree with those limitations of the procedural safeguards that would allow States to exclude from the scope of procedural rights aliens who have been unlawfully present on their territory for less than six months. ${ }^{80}$ This is capable of undermining in practice the minimum standards offered by the draft article concerned. Instead, the EU suggested to limit the possible derogation to 'border cases', where aliens are apprehended or intercepted by the competent authorities in connection with the illegal border crossing, as applied in the Return Directive. ${ }^{81}$

i) Judicial remedies play a significant role in the upholding of the rule of law, a general objective pursued by the EU. The suspensive effect of an appeal against an expulsion order was laid down in the 2012 draft articles as a general principle in the case of lawfully staying aliens. Nevertheless, the Union was not convinced about the existence of a solid basis of this guarantee under international law as it is not even a minimum standard by virtue of EU law. The Return Directive merely stipulates in its Article 13(1) that third-county nationals ('aliens' for the purpose of the ILC's work) 'shall be afforded an effective remedy to appeal

782012 EU Statement, para. 20.

79 See Guideline no 4 and Article 12(1) of the Return Directive.

${ }^{80}$ For academic commentary on these the debates within the ILC, see Pistoia (2017) 186-91.

81 Return Directive, Article 2(2) lit. a). 
against or seek review of decisions related to return [...] before a competent judicial or administrative authority or a competent body composed of members who are impartial and who enjoy safeguards of independence'. It is only coupled by the mild requirement that these competent bodies shall have the power to temporarily suspend the enforcement of the return decisions [Article 13(2)] so the remedy eo ipso should not necessarily have suspensive effect. ${ }^{82}$ There are exceptions to the suspensive effect of an appeal against expulsion decisions even for EU citizens and their family members. ${ }^{83}$ Standards of EU law applicable to aliens in this regard follow Guideline no 5 of the CoE Twenty Guidelines on Forced Return. This does not include a mandatory suspension but simply refers to the need for an effective remedy before a competent impartial and independent authority or body, which has the power to review the removal order, including the possibility of temporarily suspending its execution. Put it differently, it is not automatic but falls within the reviewing authorities' margin of discretion. Further to that, the EU argued such a generous approach to compulsory suspensive effect of return related appeals, which would clearly constitute the progressive development of international law, could also be seen as an incitement to abusing expulsion and appeal procedures to the detriment of their genuine purpose.

j) The last detailed, rather minor remark concerned the readmission to the expelling State if expulsion was unlawful. Here the EU suggested a technical/linguistic clarification in the draft article concerned to avoid misunderstandings about which competent authorities are entitled to establish whether an unlawful expulsion has occurred (those of the expelling State).

\section{THE ACTUAL IMPACT OF EU LAW ON THE ILC DRAFT ARTICLES ON THE EXPULSION OF ALIENS}

This section, following the detailed comments, remarks and concrete drafting suggestions of the EU, is devoted to examining the actual impact of EU law on the final draft articles, ultimately adopted by the ILC in 2014 on second reading.

Formally speaking, the impact of EU law first became visible in a structured manner in the eighth report of the Special Rapporteur and then a separate section similarly dealt with EU law in his ninth report. Besides these, ILC annual reports occasionally discussed the role EU law could play in this codification project. ${ }^{84}$ The ILC's approach has come a long way from the mere ignorance of EU law and the EU Commission's submissions by the special rapporteur in the early stages of the codification work until gradually taking into account major EU return legal concepts in ILC reports and in the draft articles.

82 Nevertheless, it is noteworthy that the CJEU recently took the position, following the line of the ECtHR case law, that there are cases when the competent authorities do not have discretion in this regard, but they are automatically bound to order suspensive effect. Such a case is if the illegally staying third-country national suffers from a serious illness and the enforcement of the return decision may expose the person to a serious risk of grave and irreversible deterioration of his state of health (see C-562/13, Abdida, Judgment of 18 December 2014, ECLI:EU:C:2014:2453, paras. 48-53). Cf. also Lutz and Mananashvili (2016) 725.

${ }^{83}$ Directive 2004/38/EC, Article 31.

${ }^{84}$ See e.g. the Report of the International Law Commission, Sixty-second session (3 May4 June and 5 July-6 August 2010), GAOR 65th session, Supp. No. 10, A/65/10, paras. 130, 145 and 149. 
An example illustrating the ILC's initial attitude is in response to specific questions put by the ILC in its 2009 report. In order to assist with the examination of EU law, the Legal Service of the European Commission sent a detailed letter with explanations on EU law and jurisprudence. ${ }^{85}$ This was neither distributed to the ILC members, nor considered by the special rapporteur until 2012, before the eighth report. ${ }^{86}$ Finally, the commentaries attached to the 2014 draft articles show also direct or indirect signs of influence of EU law.

Substance-wise, the EU has always recommended the ILC to take EU return law and jurisprudence into consideration, as much as possible. The Union was aware of views expressed within the ILC that 'the practices and precedents derived from special regimes, such as European Union law should be treated with caution'87, but it consistently argued that EU return law 'represents a significant regional practice that should be taken into account by the International Law, Commission in its consideration of the topic of Expulsion of Aliens' ${ }^{88}$ Furthermore, the EU, while sharing the view on the special character of EU law, believed that certain guarantees applicable to the expulsion of EU citizens and their family members may also be relevant for the formation of international law. ${ }^{89}$

Table 1, while not exhaustive, showcases the impact of individual EU comments or suggestions in the ILC draft and also where reference was made to these ideas in the commentaries.

Table 1: Changes in the final ILC draft articles due to EU influence

\begin{tabular}{|l|l|l|l|}
\hline EU comments/suggestions & $\begin{array}{l}\text { Direct influence } \\
\text { on the 2014 draft } \\
\text { articles }\end{array}$ & $\begin{array}{l}\text { Reflected } \\
\text { in the } \\
\text { commentaries }\end{array}$ & No impact \\
\hline $\begin{array}{l}\text { fundamental distinction } \\
\text { between EU citizens (and their } \\
\text { family members) and non-EU } \\
\text { nationals (third-country } \\
\text { nationals) granting privileged } \\
\text { treatment for EU citizens, who } \\
\text { enjoy the freedom of movement } \\
\text { within the Union, does not } \\
\text { amount to discrimination under } \\
\text { international law }\end{array}$ & Yes - draft article 14 & $\begin{array}{l}\text { Yes - commentary } \\
\text { to draft article 1, } \\
\text { para. 7; commentary } \\
\text { to draft article 14, } \\
\text { para. } 5^{90}\end{array}$ & - \\
\hline $\begin{array}{l}\text { specific references to the more } \\
\text { favourable conditions } \\
\text { applicable to the expulsion of } \\
\text { refugees and stateless persons }\end{array}$ & $\begin{array}{l}\text { Yes - draft articles 6 } \\
\text { and 7 }\end{array}$ & - & \\
\hline
\end{tabular}

85 JUR (2010) 50059, 22 February 2010 addressed to Mrs Patricia O'Brien, UN Legal Counsel.

862011 EU Statement, Part I.A.

872010 Report of the ILC, para. 149.

882011 EU Statement, 2 (Part I. B).

892011 EU Statement, 2 (Part I. B).

90 'The reference in the draft article to 'any other ground impermissible under international law' [...] also preserves the possibility for States to establish among themselves special legal regimes based on the principle of freedom of movement for their citizens such as the regime of the European Union.' (underlined by the author - T.M). 


\begin{tabular}{|c|c|c|c|}
\hline EU comments/suggestions & $\begin{array}{l}\text { Direct influence } \\
\text { on the } 2014 \text { draft } \\
\text { articles }\end{array}$ & $\begin{array}{l}\text { Reflected } \\
\text { in the } \\
\text { commentaries }\end{array}$ & No impact \\
\hline $\begin{array}{l}\text { inclusion of sexual orientation } \\
\text { as a ground for non- } \\
\text { discrimination }\end{array}$ & No & $\begin{array}{l}\text { Yes - commentary } \\
\text { to draft article } 14, \\
\text { para. } 4\end{array}$ & - \\
\hline $\begin{array}{l}\text { taking into account health } \\
\text { considerations in case } \\
\text { of vulnerable persons }\end{array}$ & No & $\begin{array}{l}\text { Yes - commentary } \\
\text { to draft article } 15, \\
\text { para. } 3\end{array}$ & - \\
\hline $\begin{array}{l}\text { further modalities to decide } \\
\text { on the extension of the duration } \\
\text { of detention }\end{array}$ & $\begin{array}{l}\text { Partially yes, with the } \\
\text { insertion of category of } \\
\text { 'another competent } \\
\text { authority', whose decision } \\
\text { is subject to judicial } \\
\text { review } \\
\text { [draft article } 19(2) \text { lit. (b)] }\end{array}$ & No & $\begin{array}{l}\text { Other } \\
\text { suggestions have } \\
\text { been set aside in } \\
\text { the Ninth Report } \\
\text { of the Special } \\
\text { Rapporteur } \\
\text { (paras. 51-52) }\end{array}$ \\
\hline $\begin{array}{l}\text { requiring speedy judicial } \\
\text { review on the lawfulness } \\
\text { of the detention }\end{array}$ & No & No & $\begin{array}{l}\text { Not discussed } \\
\text { at all by Special } \\
\text { Rapporteur } \\
\text { or the ILC }\end{array}$ \\
\hline $\begin{array}{l}\text { conceiving voluntary departure } \\
\text { of the returnee as the preferred } \\
\text { option over forcible } \\
\text { implementation of the expulsion } \\
\text { decision }\end{array}$ & No & $\begin{array}{l}\text { Yes - commentary } \\
\text { to draft article } 21 \text {, } \\
\text { para. } 2 \text { and footnote } \\
131\end{array}$ & - \\
\hline $\begin{array}{l}\text { insisting on the duties of the } \\
\text { receiving State to readmit its } \\
\text { own nationals }\end{array}$ & No & $\begin{array}{l}\text { Yes -commentary } \\
\text { to draft article } 22, \\
\text { para. } 1 \text {; also recalled } \\
\text { by the Ninth Report } \\
\text { of the Special } \\
\text { Rapporteur, para. } 55\end{array}$ & - \\
\hline $\begin{array}{l}\text { more precise drafting of the } \\
\text { obligation not to expel an alien } \\
\text { to a State where his or her life } \\
\text { or freedom would be threatened }\end{array}$ & Yes - draft article 23(2) & $\begin{array}{l}\text { No - references are } \\
\text { made to the practice } \\
\text { of the Human Rights } \\
\text { Committee }\end{array}$ & - \\
\hline $\begin{array}{l}\text { the right to receive a written } \\
\text { expulsion decision and the right } \\
\text { to information about available } \\
\text { legal remedies }\end{array}$ & No & No & $\begin{array}{l}\text { Discussed by the } \\
\text { Ninth Report } \\
\text { of Special } \\
\text { Rapporteur, } \\
\text { which suggested } \\
\text { a reference } \\
\text { to be included } \\
\text { in the } \\
\text { commentaries } \\
\text { on adopting } \\
\text { the expulsion } \\
\text { decision } \\
\text { in writing } \\
\text { (para. 61) but } \\
\text { was not finally } \\
\text { taken up }\end{array}$ \\
\hline
\end{tabular}




\begin{tabular}{|l|l|l|l|}
\hline EU comments/suggestions & $\begin{array}{l}\text { Direct influence } \\
\text { on the 2014 draft } \\
\text { articles }\end{array}$ & $\begin{array}{l}\text { Reflected } \\
\text { in the } \\
\text { commentaries }\end{array}$ & No impact \\
\hline $\begin{array}{l}\text { limiting the derogations from } \\
\text { procedural safeguards to } \\
\text { 'border cases' }\end{array}$ & $\begin{array}{l}\text { Partially yes - implicitly, } \\
\text { by way of a compromise } \\
\text { wording } 91 \\
\text { [draft article 26(4)] }\end{array}$ & $\begin{array}{l}\text { Yes - implicitly, } \\
\text { referring to this } \\
\text { as an exercise } \\
\text { in the progressive } \\
\text { development } \\
\text { of international law } \\
\text { (commentary to draft } \\
\text { article 26, para. 11) }\end{array}$ & - \\
\hline $\begin{array}{l}\text { no automatic suspensive effect } \\
\text { of an appeal against an } \\
\text { expulsion decision }\end{array}$ & $\begin{array}{l}\text { Yes - implicitly, by } \\
\text { narrowing down the } \\
\text { material scope of this rule } \\
\text { in the draft article } \\
\text { concerned }{ }^{92} \text { ) } \\
\text { (draft article 27) }\end{array}$ & $\begin{array}{l}\text { Yes - commentary } \\
\text { to draft article 27, } \\
\text { para. 1 }\end{array}$ & - \\
\hline $\begin{array}{l}\text { technical rectification in respect } \\
\text { of the readmission to the } \\
\text { expelling State }\end{array}$ & No & No & $\begin{array}{l}\text { This technical } \\
\text { rectification was } \\
\text { not addressed } \\
\text { at all }\end{array}$ \\
\hline
\end{tabular}

Further to the above overview of the EU's impact over substantive points, the final outcome of the ILC's work on the topic was highly debated, in relation to which the EU and several States have also expressed a position. A few States clearly supported the adoption of an international convention, e.g., Belarus, Congo, Peru, while others, like the EU, favoured the form of nonbinding documents like 'guidelines', 'guiding principles' or 'best practices of policy guidelines' ${ }^{93}$ A few States felt the final form of this codification project should be determined at a later stage, e.g., Israel, Malaysia. ${ }^{94}$ The Special Rapporteur's view was 'very few topics of the Commission's agenda have such a solid grounding in international law as does the expulsion of aliens" ${ }^{95}$ and other topics "that have been considered by the Commission and have resulted in draft articles, rather than directives, guidelines or principles, were not based on such abundant legal material' ${ }^{96} \mathrm{He}$ expressed his clear preference that the ILC should adopt draft articles and then on the basis of that, a convention should emerge. The EU's insistence on some soft law document is not completely lost as the ILC left all options open, as even if draft articles were finally adopted, the UNGA now decides what kind of normativity and bindingness to attribute to the text. Certain, so far unanswered questions arise on the issue of why the EU has preferred a soft law document

91 'The procedural rights provided for in this article are without prejudice to the application of any legislation of the expelling State concerning the expulsion of aliens who have been unlawfully present in its territory for a brief duration.' (underlined by the author - T.M).

92 'An appeal lodged by an alien [...] shall have a suspensive effect on the expulsion decision when there is a real risk of serious irreversible harm' (underlined by the author - T.M).

93 Ninth Report of the Special Rapporteur, para. 71 and footnote 214.

94 Ninth Report of the Special Rapporteur, para. 71 and footnotes 214 and 223.

95 Ninth Report of the Special Rapporteur, para. 74.

96 Eighth report of the Special Rapporteur, para. 56. 
while it has continuously insisted on having its own norms be adopted (as a nor mentrepreneur)? Has the 'soft law' ambition been the consequence of its partial success? Or does the EU really wish to maintain a double standard with high protection from expulsion for the privileged EU citizens and their third-country national family members enjoying the EU right of free movement but smooth removal of all non-EU citizens (third country nationals)?

Evaluating the EU's actual impact and influence on the ILC's codification work is a 'the glass is half full or half empty' dilemma as much depends on the perspective or the position of the assessor. The European Union obviously regretted that the final outcome on the topic did not reflect some of its concrete suggestions and that the normative value of the codification instrument is able to go beyond pure guidelines. It voiced its disappointment through the lenses of human rights protection when it underscored that a number of the unsuccessful suggestions have strong human rights character, e.g., the inclusion of sexual orientation as ground for nondiscrimination, the right to speedy judicial review of the lawfulness of detention, the right to receive a written decision, the right to information about available legal remedies or recognizing voluntary departure as the preferred option over forced return. The EU officially called on 'all UN Member States to take appropriate actions in order to guarantee these rights in cases of expulsion of aliens' despite these EU proposals not being put through the mechanisms of international lawmaking. ${ }^{97}$ Yet, the Union noted with satisfaction, that according to the ILC, its conclusions on this topic were inspired by the EU's own policy and legislation. ${ }^{98}$ Some States, to the contrary, criticized the Special Rapporteur for codifying EU law - this moderate influence was considered too much by some e.g. the United States. ${ }^{99}$

The Special Rapporteur acknowledged that the Return Directive 'contains extremely progressive provisions on such matters that are far more advanced than the norms found in other regions of the world. Although these provisions are applicable to some [thirty] States, it appears difficult to establish them as universal norms' ${ }^{100}$ - the contents of the Return Directive cannot be said to be well established in general international law. ${ }^{101}$ This very progressive character of the Return Directive partly explains the limits of its impact on the ILC's work.

The other side of the situation is the somewhat different material scope of the Return Directive and/or generally EU law on expulsion as compared to the draft articles. EU law does not have specific, explicit rules concerning the return of an expelled alien to the expelling State, if that measure was originally unlawful. Secondly, EU legislation does not deal explicitly with the legal relations between the expelling State and the transit State(s), although this issue is addressed in the readmission agreements concluded between the Union and third-countries. There are currently 17 bilateral EU-level readmission agreements in force, ${ }^{102}$ not mentioning certain multilateral agreements concluded by the Union with

972014 EU Statement.

982014 EU Statement.

99 Eighth report of the Special Rapporteur, para. 42.

100 Eighth report of the Special Rapporteur, para. 42.

101 Second addendum to the Sixth Report of the Special Rapporteur, A/CN.4/625/Add.2, 9 July 2010, para.15.

102 For an overview of the 17 bilateral EU-level readmission agreements that are in force, see $<$ http://www.consilium.europa.eu/en/documents-publications/agreements-conventions/search-results/ $? \mathrm{dl}=\mathrm{EN} \&$ title $=$ readmission $\&$ from $=0 \&$ to $=0>$ accessed 30 April 2017. 
third-countries containing a readmission clause such as the Cotonou Agreement. ${ }^{103}$ These essentially constitute an area of bilateral cooperation, where the EU and third States are free to agree on rules that they wish to apply in their bilateral relations, provided that these norms of jus dispositivum do not violate the peremptory norms of international law (jus cogens). ${ }^{104}$ The treaty practice reflected in the readmission agreements concluded by the EU was thus not suitable for universal codification, and no further general rules can be deduced or uniform practice can be determined from the ever-growing web of readmission agreements. ${ }^{105}$

\section{CONCLUSIONS}

Co-shaping international law has been essential for the EU from the very beginning of the integration process. This tenet holds particularly true through the lenses of the EU's strategically exercised normative influence on international migration law in the field of expulsion of aliens. Remarkably, the analysis of the EU's contribution to the conceptualization and development of this specific branch of international migration law, either on the universal or the regional level, has not yet received much academic attention.

Assessing the inroads that EU return law made in the universal law-making, notably with regard to the 2014 ILC draft articles on the expulsion of aliens, the effectiveness of this normative influence might be debated but some tangible, results as depicted above, cannot be denied. It is beyond doubt that the European Union has placed itself in the UN context as a serious global player and norm-creator in the subject matter of expulsion of aliens. Likewise, the whole exercise, coupled with other EU interventions on topics discussed by the ILC c.f., the responsibility of international organizations, the protection of persons in the event of disasters or the identification of customary international law, filled Articles 3(5) and 21(1) TEU with content and contributed to improving the Union's image as a respected and committed partner for a more coherent multilayered migration governance with the view to projecting converging legal standards. Both Union law and the ILC draft articles serve to pursue the same goals and defend the same values - 'any person who is subject to expulsion measures should be treated with respect for that person's human dignity and in accordance with agreed minimum standards, based on the rule of law. ${ }^{106}$ The UNGA discusses the topic again in autumn 2017 with a view to deciding whether to endorse the draft articles in form of an UNGA resolution, hence officially concluding the codification process (as was the case with a number of ILC projects before) or to convene a diplomatic conference to elaborate a legally binding convention on the basis of the draft articles. This latter would definitely offer a renewed occasion for the EU to leave a considerable mark on the outcome of such intergovernmental negotiations.

Looking at the future, the EU will likely to continue to regionally exporting its norms within the Council of Europe framework, whose standard-setting activities have already

103 Partnership agreement between the members of the African, Caribbean and Pacific Group of States of the one part, and the European Community and its Member States, of the other part, signed in Cotonou on 23 June 2000 (OJ L 317, 15.12.2000), Article 13.

104 Eighth report of the Special Rapporteur, para. 48; Ninth report of the Special Rapporteur, para. 19.

105 See e.g. the MIREM project and its continuation <http://www.jeanpierrecassarino.com/ datasets/ra/> accessed 30 April 2017.

1062012 EU Statement, para. 7. 
been tangibly influenced and shaped by EU developments in this area of law. A call from the European Commission addressed to the Council of Europe early $2014^{107}$ resulted in the CoE being engaged in the elaboration of European Immigration Detention Rules by the end of 2019 under the aegis the European Committee on Legal Co-operation (CDCJ), within which an expert group on the administrative detention of migrants (CJ-DAM) has been created. ${ }^{108}$ This project, which aims at embarking on Europe-wide standard setting, will admittedly build upon EU norms in a large extent. Hence a new occasion is going to present itself to conduct a similar analysis at the regional level. The outcome of this project within the CoE should be the subject of a new study in the quest of exploring how far (regional) international law becomes Europeanised by interaction with EU law. This will probably also open the discourse to evaluate that at which level of regulation the expulsion of aliens would best be addressed. Stay tuned!

\section{LITERATURE}

Acosta Arcarazo, Diego, Latin American Reactions to the Adoption of the Returns Directive, (CEPS Liberty and Security in Europe publication series, November 2009) <https://www.ceps.eu/system/ files/book/2009/11/latin-american-reactions-adoption-returns-directive.pdf $>$ accessed 30 April 2017.

Aleinkoff, T. Alexander, 'International Legal Norms on Migration: Substance without Architecture' in Cholewinski, Richard, Perruchoud, Richard and MacDonald, Euan (eds), International Migration Law. Developing paradigms and Key Challenges (T.M.C. Asser Press 2007) 467-80.

Basu, Sudeshna, Schunz, Simon, Bruyninckx, Hans and Wouters, Jan, 'The European Union's Participation in United Nations Human Rights and Environmental Governance: Key Concepts and Major Challenges' in Wouters, Jan et al (eds), The European Union and Multilateral Governance: Assessing EU Participation in United Nations Human Rights and Environmental Fora (Palgrave Macmillan 2012) 3-22.

Bergé, Jean-Sylvestre, Les interactions entre le droit international et européen - Approche du phénomène en trois étapes dans le contexte européen (2009) Aequitas Virtual, Publicaciòn de la Facultad de Ciencias Jurídicas, Universidad del Salvador (Repùblica Argentina), <http://p3.usal. edu.ar/index.php/aequitasvirtual/article/download/951/1134> accessed 30 April 2017.

Brouwer, Evelien and de Vries, Karin, 'Third-country nationals and discrimination on the ground of nationality: article 18 TFEU in the context of article 14 ECHR and EU migration law: time for a new approach' in van den Brink, Marjolein and others (eds), Equality and Human Rights: Nothing But Trouble? Liber Amicorum Titia Loenen (SIM Publications 2015) 124-46.

Farahat, Anuscheh, 'Enhancing Constitutional Justice by Using External References: The European Court of Human Rights' Reasoning on the Protection against Expulsion' (2015) 28 Leiden Journal of International Law 303-22.

Goodwin-Gill, Guy S. and McAdam, Jane, The Refugee in International Law (3rd edition, Oxford University Press 2007)

107 Communication from the Commission to the Council and the European Parliament on EU Return Policy (COM(2014) 199 final, Brussels, 28.3.2014), where the Commission gently requested the Council of Europe 'to codify a set of detailed immigration detention rules based on existing international and regional human rights standards applicable to deprivation of liberty on the grounds of immigration status' (Part III. 2.).

108 See $<$ http://www.coe.int/t/dghl/standardsetting/cdcj/Administrative\%20detention $\% 20 \mathrm{of} \% 20$ migrants/administration_detention_migrants_en.asp $>$ accessed 30 April 2017. On the latest developments of this codification exercise, consider, e.g. <http://www.osce.org/odihr/321156> accessed 30 June 2017 and <http://ennhri.org/ENNHRI-inputs-to-the-first-draft-of-European-ImmigrationDetention-Rules> accessed 30 June 2017. 
Gyeney, Laura and Molnár, Tamás, 'The Immigration and Asylum Policy of the European Union' in Láncos, Petra Lea and others (eds), Union Policies (Eleven International Publishing 2016) $183-249$.

Hailbronner, Kay and Thym, Daniel, 'Constitutional Framework and Principles for Interpretation' in Hailbronner, Kay and Thym, Daniel (eds), EU Immigration and Asylum Law. A Commentary ( $2^{\text {nd }}$ edn, C.H.Beck/Hart/Nomos 2016) 1-29.

Joseph, Sarah and Castan, Melissa, The International Covenant on Civil and Political Rights: Cases, Materials and Commentary ( $3^{\text {rd }}$ edn, Oxford University Press 2013).

Kochenov, Dimitriy and Amtenbrink, Fabian, The European Union's Shaping of the International Legal Order (Cambridge University Press 2014).

Lambert, Hélène, The position of aliens in relation to the European Convention on Human Rights (Council of Europe Publishing 2007).

Lillich, Richard B., The Human Rights of Aliens in Contemporary International Law (Manchester University Press 1984).

Lutz, Fabian and Mananashvili, Sergo, 'Return Directive 2008/115/EC' in Hailbronner, Kay and Thym, Daniel (eds.), EU Immigration and Asylum Law. A Commentary ( $2^{\text {nd }}$ edn, C.H.Beck/Hart/ Nomos 2016) 658-763.

Maes, Marleen, Vanheule, Dirk, Wouters, Jan and Foblets, Marie-Claire, 'The international dimension of EU asylum and migration policy: framing the issues' in Maes, Marleen and others (eds), External Dimensions of EU Migration and Asylum Law and Policy/Dimensions Externes du Droit et de la Politique d'Immigration et d'Asile de l'UE (Bruylant 2011) 9-60.

Morano-Foadi, Sonia and Andreadakis, Stelios, 'The Convergence of the European Legal System in the Treatment of Third Country Nationals in Europe: The ECJ and ECtHR Jurisprudence' (2011) 22 European Journal of International Law 1071-88.

Murphy, Sean D., 'The Expulsion of Aliens and Other Topics: The Sixty-Fourth Session of the International Law Commission' (2013) 107 American Journal of International Law 164-77.

Murphy, Sean D., 'The Expulsion of Aliens (Revisited) and Other Topics: The Sixty-Sixth Session of the International Law Commission' (2014) 59 George Washington University Law School Public Law and Legal Theory Paper <http://ssrn.com/abstract=2540098> accessed 30 April 2017.

Nowak, Manfred, U.N. Covenant on Civil and Political Rights. CCPR Commentary $\left(2^{\text {nd }}\right.$ edn, N.P. Engel Publisher 2005).

Peers, Steve, 'International law, human rights law and EU asylum and migration policy' in Maes, Marleen and others (eds), External Dimensions of EU Migration and Asylum Law and Policy/ Dimensions Externes du Droit et de la Politique d'Immigration et d'Asile de l'UE (Bruylant 2011) $63-88$.

Pistoia, Emmanuela, 'Procedural Rights of Illegal Migrants Facing Expulsion in Contemporary Times: Exploring Synergies Between the ILC Draft Articles and the EU Returns Directive' in Acconci, Pia et al (eds), International Law and the Protection of Humanity: Essays in Honor of Flavia Lattanzi (Brill/Nijhoff 2017) 182-95.

Simma, Bruno and Pulkowski, Dirk, 'Of Planets and the Universe: Self-contained Regimes in International Law' (2006) 17 European Journal of International Law 483-529.

Tomuschat, Christian, 'Expulsion of aliens: the International Law Commission draft article' in Jochum, Georg et al (eds), Grenzüberschreitendes Recht - Crossing Frontiers Festschrift für Kay Hailbronner (C.F. Müller 2013) 645-62.

van Vooren and others (eds), The EU's Role in Global Governance: The Legal Dimension (Oxford University Press 2013).

Wouters, Jan and Hermez, Marta, 'The EU's contribution to the 'strict observance' and development of international law in the UNGA Sixth Committee' (2016 October) 177 Leuven Centre for Global Governance Studies Working Paper <https://ghum.kuleuven.be/ggs/wp177-wouters-hermez.pdf> accessed 30 April 2017.

Ziegler, Katja S., 'International law and EU law: between asymmetric constitutionalisation and fragmentation' in Orakhelashvili, Alexander (ed), Research Handbook on the Theory and History of International Law (Edward Elgar 2011) 268-327. 